\title{
Opsonic activity in serum from septic infants treated with intravenous immunoglobulin
}

\author{
L MARÓDI, Á KALMÁR, AND I SZABÓ \\ Department of Paediatrics, University Medical School of Debrecen, Hungary
}

SUMMARY Thirteen infants with staphylococcal sepsis and reduced opsonic activity received infusions of acid treated immunoglobulin together with antibiotics. Opsonic activity (using Staphylococcus aureus (type 42D) as the test organism), haemolytic activity of complement, and concentrations of complement $\mathrm{C} 3$ and $\mathrm{IgG}$ were measured in serum prepared before and after three days of treatment with immunoglobulin at a dose of $250-300 \mathrm{mg} / \mathrm{kg} / \mathrm{day}$. There was increased ingestion of $S$ aureus by normal human granulocytes in the presence of fresh serum prepared after infusion of immunoglobulin and significantly increased opsonic activity of heat inactivated serum after treatment with immunoglobulin. The haemolytic activity of complement and concentrations of complement $\mathrm{C} 3$ were not influenced, and serum concentrations of IgG increased as the result of receiving a total of $800-900 \mathrm{mg} / \mathrm{kg}$ immunoglobulin over a period of three days. This study shows that administration of acid treated IgG to septic infants leads to functionally increased opsonisation.

Intravenous immunoglobulin is the treatment of choice for agammaglobulinaemia or hypogammaglobulinaemia. In patients with normal concentrations of gammaglobulin, immunoglobulins exert an immunomodulatory function. ${ }^{12}$ High doses of immunoglobulins produce rapid increases in the platelet counts in patients with idiopathic thrombocytopenic purpura. ${ }^{13}$ Intravenous immunoglobulins alone or with antiviral drugs may improve the efficacy of treatment of life threatening viral diseases, apparently by replacement of selectively missing or exhausted antibodies. ${ }^{2}$ The combined use of intravenous immunoglobulins and antibiotics is effective in the treatment of neonatal sepsis, particularly in premature infants. ${ }^{45}$

Intravenous immunoglobulins contribute to antibacterial host defense by opsonising microorganisms. Binding of specific antibodies of the $\mathrm{IgG}$ class, with or without subsequent binding of complement to the surface of bacteria, facilitates phagocytosis by granulocytes or mononuclear phagocytes. ${ }^{6-8}$ In vitro studies have shown that intravenous immunoglobulin preparations that contain intact $7 \mathrm{~S}$ IgG could mediate reasonable opsonic activity towards a number of bacterial pathogens and could enhance phagocytosis of these micro-organisms by granulocytes. ${ }^{9}$ Addition of such a preparation to serum from neonates resulted in increased phagocy- tosis of group B streptococcus type III in the presence of adult granulocytes. ${ }^{10}$

In this study we report increased opsonisation using $S$ aureus as the test organism in young infants receiving intravenous immunoglobulin for the treatment of established staphylococcal infection.

\section{Patients and methods}

Selected clinical and laboratory data of the 13 infants studied are shown in table 1. All these infants had septicaemia or other severe bacterial infections (meningitis, ventriculitis, pneumonia) caused by $S$ aureus either singly or in combination with another bacterial pathogen. Congenital malformations in cases $4,8,9$, and 12 could have been predisposing factors for the development of the severe infection. Case 13 developed a paraoesophageal abscess after swallowing a drawing pin that stuck in the oesophagus. When these patients presented with severe symptoms or septicaemia, or both, informed consent was obtained from the parents and conventional treatment with antibiotics was supplemented with intravenous immunoglobulin $250-300 \mathrm{mg} / \mathrm{kg} /$ day for three consecutive days. When immunoglobulin treatment was started, all the patients had already been receiving antibiotics for more than two days. During the immunoglobulin 
Table 1 Details of patients treated with immunoglobulin

\begin{tabular}{|c|c|c|c|c|c|c|c|c|}
\hline $\begin{array}{l}\text { Case } \\
\text { No }\end{array}$ & $\begin{array}{l}\text { Birth } \\
\text { weight } \\
(g)\end{array}$ & $\begin{array}{l}\text { Gestational } \\
\text { age } \\
\text { (weeks) }\end{array}$ & $\begin{array}{l}\text { Age of } \\
\text { patient }\end{array}$ & Sex & Clinical diagnosis & $\begin{array}{l}\text { Polymorpho- } \\
\text { nuclear } \\
\text { leucocytes } \\
\left(\times 10^{9} / l\right)\end{array}$ & $\begin{array}{l}\text { Source of } \\
\text { bacteria }\end{array}$ & $\begin{array}{l}\text { Bacteria } \\
\text { cultured }\end{array}$ \\
\hline 1 & 3500 & 41 & 2 Days & Female & $\begin{array}{l}\text { Meconium aspiration, } \\
\text { septicaemia }\end{array}$ & $4 \cdot()$ & Blood & $\begin{array}{l}S \text { aureus, Klebsiella } \\
\text { species }\end{array}$ \\
\hline 2 & 3300 & 37 & 3 Days & Female & Septicaemia & $10 \cdot 0$ & Blood & $S$ aureus \\
\hline 3 & 2800 & 35 & 5 Days & Male & $\begin{array}{l}\text { Intracranial haemorrhage, } \\
\text { septicacmia }\end{array}$ & $6 \cdot 0$ & Blood & $\begin{array}{l}S \text { aureus, Klebsiella } \\
\text { species }\end{array}$ \\
\hline 4 & 3000 & 37 & 7 Days & Female & Meningocele, meningitis & $7 \cdot 6$ & $\begin{array}{l}\text { Cerebrospinal } \\
\text { fluid }\end{array}$ & $S$ aureus \\
\hline 5 & 3600 & 38 & 9 Days & Male & Umbilical sepsis, septicaemia & $10 \cdot 5$ & Blood & $S$ aureus \\
\hline 6 & 3450 & 38 & 3 Weeks & Female & Pncumonia, septicaemia & $9 \cdot 8$ & Blood & $S$ aureus \\
\hline 7 & 2500 & 33 & 4 Weeks & Male & Pneumonia & $10 \cdot 4$ & Pus & $S$ aureus \\
\hline 8 & 3900 & 40 & 6 Weeks & Male & $\begin{array}{l}\text { Hypoplastic lungs, } \\
\text { pncumonia }\end{array}$ & $4 \cdot 6$ & Pus & $\begin{array}{l}S \text { aureus, Pseudomonas } \\
\text { aeruginosa }\end{array}$ \\
\hline 9 & 3200 & 40 & 8 Weeks & Female & $\begin{array}{l}\text { Hypoplastic cricoid, } \\
\text { septicaemia }\end{array}$ & $14 \cdot 0$ & Blood & $S$ aureus \\
\hline 10 & 2450 & 40 & 8 Weeks & Female & Ventriculitis, septicacmia & $8 \cdot 0$ & $\begin{array}{l}\text { Blood, } \\
\text { cerebrospinal } \\
\text { fluid }\end{array}$ & $\begin{array}{l}S \text { aureus, Pseudomonas } \\
\text { aeruginosa }\end{array}$ \\
\hline 11 & 3200 & 37 & 6 Months & Female & Mastoiditis, septicaemia & $14 \cdot 6$ & Blood & $S$ aureus \\
\hline 12 & 3400 & 39 & 8 Months & Male & $\begin{array}{l}\text { Hydrocephalus, shunt, } \\
\text { septicacmia }\end{array}$ & $12 \cdot 6$ & $\begin{array}{l}\text { Blood, cerebro- } \\
\text { spinal fluid }\end{array}$ & $S$ aureus \\
\hline 13 & 2150 & 35 & 9 Months & Female & $\begin{array}{l}\text { Paraoesophageal abscess, } \\
\text { septicaemia }\end{array}$ & $13 \cdot 8$ & Blood, pus & $S$ aureus \\
\hline
\end{tabular}

Table 2 Details of control patients

\begin{tabular}{|c|c|c|c|c|c|c|c|c|}
\hline $\begin{array}{l}\text { Case } \\
\text { No }\end{array}$ & $\begin{array}{l}\text { Birth } \\
\text { weight } \\
(g)\end{array}$ & $\begin{array}{l}\text { Gestational } \\
\text { age } \\
\text { (weeks) }\end{array}$ & $\begin{array}{l}\text { Age of } \\
\text { patient }\end{array}$ & Sex & Clinical diagnosis & $\begin{array}{l}\text { Polymorpho- } \\
\text { nuclear } \\
\text { leucocytes } \\
\left(\times 10^{y} / l\right)\end{array}$ & $\begin{array}{l}\text { Source of } \\
\text { bacteria }\end{array}$ & $\begin{array}{l}\text { Bacteria } \\
\text { cultured }\end{array}$ \\
\hline 1 & 2800 & 36 & 2 Days & Female & $\begin{array}{l}\text { Infantile respiratory } \\
\text { distress syndrome, } \\
\text { pneumonia, septicaemia }\end{array}$ & $11 \cdot 0$ & Blood & $\begin{array}{l}S \text { aureus, Escherichia } \\
\text { coli }\end{array}$ \\
\hline 2 & 2650 & 36 & 2 Days & Female & $\begin{array}{l}\text { Oesophageal atresia, } \\
\text { pneumonia }\end{array}$ & $10 \cdot 4$ & Pus & $S$ aureus \\
\hline 3 & 2100 & 33 & 3 Days & Female & $\begin{array}{l}\text { Meconium aspiration, } \\
\text { respiratory distress } \\
\text { syndrome, septicaemia }\end{array}$ & $11 \cdot 5$ & Blood & $\begin{array}{l}S \text { aureus, Klebsiella } \\
\text { species }\end{array}$ \\
\hline 4 & 2100 & 34 & 5 Days & Male & $\begin{array}{l}\text { Aspiration pneumonia, } \\
\text { septicaemia }\end{array}$ & $9 \cdot 4$ & Blood & $\begin{array}{l}S \text { aureus, Pseudomonas } \\
\text { aeruginosa }\end{array}$ \\
\hline 5 & 2700 & 40 & 6 Days & Female & $\begin{array}{l}\text { Thrombophlebitis, } \\
\text { septicaemia }\end{array}$ & $6 \cdot 1$ & Blood & $\begin{array}{l}S \text { aureus, Klebsiella } \\
\text { species }\end{array}$ \\
\hline 6 & 2200 & 31 & 3 Weeks & Female & $\begin{array}{l}\text { Umbilical sepsis, } \\
\text { septicaemia }\end{array}$ & $8 \cdot 2$ & Blood & $\begin{array}{l}S \text { aureus, Staphylococcus } \\
\text { epidermidis }\end{array}$ \\
\hline 8 & 2900 & 38 & 10 Weeks & Male & Otitis medis, septicaemia & $3 \cdot 1$ & Blood & $\begin{array}{l}S \text { aureus, Pseudomonas } \\
\text { aeruginosa }\end{array}$ \\
\hline 9 & 3200 & 37 & 5 Months & Female & Pneumonia, septicaemia & $6 \cdot 2$ & Blood & $S$ aureus \\
\hline 10 & 3100 & 40 & 5 Months & Malc & Retropharyngeal abscess & $13 \cdot 6$ & Pus & $S$ aureus \\
\hline 11 & 2100 & 34 & 9 Months & Female & $\begin{array}{l}\text { Ostcomyclitis of tibia, } \\
\text { septicaemia }\end{array}$ & $17 \cdot 2$ & Blood & $S$ aureus \\
\hline 12 & 3550 & 40 & 10 Months & Female & Osteomyelitis of humerus & $13 \cdot 4$ & Pus & $S$ aureus \\
\hline 13 & 3000 & 40 & 12 Months & Female & Pneumonia & $7 \cdot 6$ & Pus & $S$ aureus \\
\hline
\end{tabular}

treatment none of the patients received blood or other blood products.

Table 2 shows the clinical and laboratory data of 13 infants who were reviewed retrospectively and acted as a historical control group. The criteria for selecting a patient as a control were one or more cultures of $S$ aureus from blood or pus together with documented signs and symptoms consistent with septicaemia or other severe bacterial infection. Five patients were less than 2 weeks old, and the rest between 3 weeks and 12 months. There were seven patients with septicaemia, three with pneumonia, two with osteomyelitis (one with septicaemia), and one with a retropharyngeal abscess.

Blood samples were taken twice during the period of immunoglobulin treatment: before the first dose 
of acid treated ( $\mathrm{pH} 4$ ) immunoglobulin was given, and on the day after the three days of treatment. The first of the two daily doses of antibiotics was always given after blood had been collected. For the control experiments blood was obtained from age matched healthy infants. Serum was prepared by clotting the blood for one hour at room temperature followed by centrifugation for 20 minutes at $1200 \mathrm{~g}$, and aliquots were stored at $-30^{\circ} \mathrm{C}$. Inactivated serum was prepared by heating serum for 30 minutes at $56^{\circ} \mathrm{C}$.

Granulocyte enriched cell suspensions were prepared from the blood of healthy adult donors by Dextran sedimentation of the erythrocytes as previously described, and suspended in Hanks's balanced salt solution with $0 \cdot 1 \%$ gelatine to a final concentration of $10^{7} \mathrm{cells} / \mathrm{ml} .1112$

$S$ aureus type $42 \mathrm{D}$ was cultured overnight at $37^{\circ} \mathrm{C}$ in nutrient broth (Oxoid), harvested by centrifugation at $1500 \mathrm{~g}$ for 10 minutes, washed twice with phosphate buffered saline, and resuspended in gelatine and Hanks's balanced salt solution to a concentration of about $10^{7}{\text { bacteria } / \mathrm{ml}^{7}}^{7}$

Titration of complement by the classical pathway was performed according to the method of Kabat and Mayer. ${ }^{13}$ Serum concentrations of complement $\mathrm{C} 3$ and IgG were measured by radial immunodiffusion using specific antisera (Human, Budapest). Serum samples prepared before and after infusion of intravenous immunoglobulin were tested individually from each patient.

The opsonic activity of serum was defined as its capacity to promote ingestion of bacteria by granulocytes. One hundred microlitres of a suspension of granulocytes (concentration $10^{7} / \mathrm{ml}$ ) were incubated with an equal volume of a suspension of $10^{7}$ bacteria/ $\mathrm{ml}$ in various concentrations of serum, and mixed by tumbling $(4 \mathrm{rpm})$ at $37^{\circ} \mathrm{C}$. After 60 minutes of phagocytosis, $50 \mu \mathrm{l}$ aliquots of the mixture were added to $450 \mu \mathrm{l}$ of ice cold Hanks's balanced salt solution, and cells were pelleted by centrifugation for 6 minutes at $75 \mathrm{~g}$. The number of viable extracellular bacteria was determined by microbiological assay. ${ }^{7}$ The opsonic activity of serum before and after infusion of intravenous immunoglobulin was determined individually from each infant. The viability of granulocytes after 60 minutes of phagocytosis remained higher than $96 \%$ (checked by trypan blue exclusion).

Phagocytosis of $S$ aureus by normal human granulocytes at a concentration of $5 \times 10^{6} / \mathrm{ml}$ at $1: 1$ bacterium:cell ratio in the presence of fresh or heat inactivated sera from patients was measured before and after a three day treatment with acid treated intravenous immunoglobulin. Serum samples from age matched healthy infants were used in control experiments. Percentages of phagocytosed bacteria were determined by colony counts after 60 minutes incubation (table 3).

An acid treated intravenous immunoglobulin concentrate (Sandoz AG) prepared at $\mathrm{pH} 4$ was administered to the patients by slow infusion in a dose of $250-300 \mathrm{mg} / \mathrm{kg}$ daily for three days.

Statistical analysis of the data was carried out by standard methods. ${ }^{14}$ The significance of differences was assessed by the unpaired $t$ test.

\section{Results}

Intravenous immunoglobulin treatment was well tolerated without side effects. All except case 1 recovered from the acute bacterial infection; she died of meconium aspiration followed by septicaemia. Cases 12 and 13 developed hydrocephalus and oesophageal stenosis, respectively. The rest of the treated patients recovered without complications. No clinical signs or symptoms of septic shock were observed.

In the control group of 13 infants (including five neonates) with septicaemia or other severe $S$ aureus infections who were given only conventional antibiotic treatment, three patients (cases 1,3 , and 7) died, and one (case 2) recovered with complications. The others recovered from the bacterial infection without complications. Days in hospital, duration of fever, and dosage of antibiotics were all about the same in the two groups. There were no significant differences in time from the onset of symptoms of infection to administration of antimicrobial drugs between study patients and controls (mean (SD) number of days, $2.9(1.8)$ compared with $3.2(2 \cdot 0)$.

Before treatment with immunoglobulin was introduced patients' serum opsonised $S$ aureus less effectively than serum from age matched controls. After three days of treatment with immunoglobulin, opsonisation of $S$ aureus by both fresh and heat inactivated serum increased, and was similar to that of the control values for all serum concentrations tested (table 3). Mean differences, between opsonic values before and after infusion were higher when heat inactivated serum samples were used as a source of opsonins than when fresh serum samples were used (table 3 and 4). This might be explained by the combined effect of complement and immunoglobulins in opsonising $S$ aureus in fresh serum. In heat inactivated serum, however, the activity of complement is abolished and opsonisation of bacteria is related mainly to the concentration and functional activity of IgG. Differences between opsonic values in fresh and heat inactivated serum taken before and after intravenous infusion of immunoglobulin were significant (table 4). 
Table 3 Phagocytosis promoting activity of serum from 13 infants with severe sepsis treated with immunoglobulin. Figures are mean $(S D)$ of 13 experiments

\begin{tabular}{|c|c|c|c|c|}
\hline & \multirow[t]{2}{*}{$\begin{array}{l}\text { Concentration of } \\
\text { serum }(\%)\end{array}$} & \multicolumn{2}{|c|}{$\begin{array}{l}\text { Percentage phagocytosed bacteria in the presence of patients' } \\
\text { sera }\end{array}$} & \multirow[t]{2}{*}{ Control sera } \\
\hline & & Before treatment & After treatment & \\
\hline \multicolumn{5}{|c|}{$\begin{array}{l}\text { Incubation of granulocytes } \\
\text { and bacteria with: }\end{array}$} \\
\hline Fresh serum & $\begin{array}{r}10 \\
5 \\
1\end{array}$ & $\begin{array}{l}72.9(14.3) \\
72.0(12.9) \\
58.9(13.6)\end{array}$ & $\begin{array}{l}96 \cdot 8(6 \cdot 0) \\
86 \cdot 7(10 \cdot 7) \\
74 \cdot 7(9 \cdot 8)\end{array}$ & $\begin{array}{l}94.8(2.9) \\
92 \cdot 3(12 \cdot 5) \\
78.4(10 \cdot 7)\end{array}$ \\
\hline $\begin{array}{l}\text { Heat inactiva } \\
\text { serum }\end{array}$ & $\begin{array}{r}10 \\
5 \\
1\end{array}$ & $\begin{array}{c}22 \cdot 8(10 \cdot 2) \\
21 \cdot 8(13 \cdot 8) \\
7 \cdot 9(6 \cdot 7)\end{array}$ & $\begin{array}{l}63 \cdot 5(14 \cdot 3) \\
58 \cdot 1(12 \cdot 8) \\
38 \cdot 2(12 \cdot 3)\end{array}$ & $\begin{array}{l}59.4(10.4) \\
58.5(9 \cdot 2) \\
32.9(9.9)\end{array}$ \\
\hline
\end{tabular}

Table 4 Statistical evaluation of the effect of treatment with intravenous immunoglobulin on opsonic activity of serum from 13 infants with severe sepsis

\begin{tabular}{|c|c|c|c|c|}
\hline Concentration (\%) & $\begin{array}{l}\text { Mean differences } \\
(\%)\end{array}$ & $\begin{array}{l}S E \text { of mean } \\
\text { differences }\end{array}$ & $\begin{array}{l}\text { Confidence } \\
\text { intervals (\%) }\end{array}$ & p Value \\
\hline \multicolumn{5}{|l|}{ Fresh serum: } \\
\hline 10 & $23 \cdot 9$ & 4.02 & 15.1 to 32.6 & $<0.001$ \\
\hline 5 & $14 \cdot 7$ & $4 \cdot 64$ & $4 \cdot 6$ to $24 \cdot 8$ & $<0.01$ \\
\hline 1 & $15 \cdot 8$ & $4 \cdot 65$ & 5.6 to 25.9 & $<0.01$ \\
\hline \multicolumn{5}{|c|}{ Heat inactivated serum: } \\
\hline 10 & $40 \cdot 8$ & $4 \cdot 89$ & $30 \cdot 1$ to $51 \cdot 4$ & $<0.001$ \\
\hline 5 & $36 \cdot 3$ & $5 \cdot 21$ & 24.9 to 47.7 & $<0.001$ \\
\hline 1 & $30 \cdot 3$ & 4.09 & 21.4 to 39.2 & $<0.001$ \\
\hline
\end{tabular}

Table 5 In vitro growth of $S$ aureus in the presence of heat inactivated sera from 13 infants with severe sepsis treated with immunoglobulin

\begin{tabular}{lll}
\hline $\begin{array}{l}\text { Time of serum } \\
\text { preparation }\end{array}$ & $\begin{array}{l}\text { Concentration of } \\
\text { serum (\%) }\end{array}$ & $\begin{array}{l}\text { Mean }(\text { SD)\% of } \\
\text { viable bacteria }\end{array}$ \\
\hline Before treatment: & 10 & $138(19 \cdot 2)$ \\
& 5 & $130(18 \cdot 5)$ \\
After treatment: & 1 & $131(20 \cdot 1)$ \\
& 10 & $129(17 \cdot 6)$ \\
& 5 & $132(18 \cdot 2)$ \\
& 1 & $121(14 \cdot 8)$ \\
\hline
\end{tabular}

The bactericidal activity of serum from the study patients was measured by the in vitro growth of $S$ aureus in various concentrations of heat inactivated sera (table 5). Incubation of bacteria without granulocytes in heat inactivated serum showed an increase in the number of micro-organisms, which indicated that there was no bactericidal activity in the samples tested. The number of viable bacteria after 60 minutes' incubation was about the same in the serum samples taken before and after treatment with immunoglobulin (table 5).

Haemolytic activity of the classical complement pathway was not influenced by immunoglobulin treatment (table 6). The same was true for concentrations of complement $\mathrm{C} 3$, whereas the serum concentration of IgG was significantly increased by the total of $800-900 \mathrm{mg}$ immunoglobulin given over the three day period.

\section{Discussion}

$S$ aureus and other staphylococci cause a diverse group of infections. $S$ aureus accounts for more than $10 \%$ of nosocomial infections and causes $20 \%$ of infections in paediatric wards. ${ }^{15}$ Polymorphonuclear neutrophil leucocytes play a key part in the host

Table 6 Haemolytic activity of complement and concentrations of complement C3 and IgG in serum from infants with severe sepsis treated with immunoglobulin. Figures are mean (SD)

\begin{tabular}{llrl}
\hline & $\begin{array}{l}\text { Before } \\
\text { treatment }\end{array}$ & $\begin{array}{l}\text { After } \\
\text { treatment }\end{array}$ & $p$ Value \\
\hline Complement haemolytic & & & \\
activity (U/ml) & $37.50(5 \cdot 10)$ & $36.20(3.90)$ & NS \\
Complement C3 (g/l) & $0.80(0 \cdot 15)$ & $0.86(0.18)$ & NS \\
IgG (g/l) & $7.70(1.90)$ & $12.80(1.80)$ & $<0.01$ \\
\hline
\end{tabular}


defence against staphylococci, yet without opsonins they inhibit $S$ aureus only to a limited extent. ${ }^{16}$ Complement clearly augments inhibition in vitro, but alone it is not impressive. ${ }^{17}$ Although the role of specific antibodies in protection against infection with $S$ aureus is not completely understood, it is known that IgG is essential to inhibit $S$ aureus even at a concentration of $0.25 \mathrm{~g} / \mathrm{l} .{ }^{16}$ Defects in antibody mediated opsonisation can occur as primary deficiencies of immunoglobulin synthesis or can be a consequence of sytemic infection caused by consumption of specific antibodies by the infecting organism.

In this study we found that both IgG mediated and IgG and complement mediated opsonic activity against $S$ aureus could be improved in infants with $S$ aureus septicaemia by treatment with intravenous immunoglobulin; the infused IgG resulted in functionally increased opsonisation. The presence of specific antibodies in the polyvalent IgG preparations against common bacterial pathogens may explain this. Indeed, the IgG preparations are fractionated from a pool of several thousand blood donations, so that antibodies to endemic pathogens are concentrated and rare antibodies are diluted.

The higher rate of ingestion of $S$ aureus by normal granulocytes in fresh serum compared with heat inactivated serum suggested that opsonisation was optimal when complement was functional. These results further emphasise the contributory effect of complement in the opsonisation of micro-organisms. The significant improvement of the opsonic activity of heat inactivated serum after infusion of immunoglobulin could be explained by the action of heat stable opsonins, specific IgG antibodies directed against the given pathogen.

The growth of bacteria in various concentrations of heat inactivated serum taken before treatment was comparable with that in serum taken after treatment with immunoglobulin. This excludes the possibility of improved opsonisation of $S$ aureus by the antibiotics that were given at the same time as the immunoglobulin to all the patients.

It is important to point out that the haemolytic activity of complement and concentrations of complement C3 were not significantly influenced by treatment with immunoglobulin. This suggests that administration of high dose immunoglobulin did not result in impairment of complement mediated effector function in septicaemic infants.

These results indicate that treatment with intravenous immunoglobulin may be useful in modifying disease caused by $S$ aureus in infants. Further evaluation will require a prospective, controlled study of the use of intravenous immunoglobulin in septicaemic infants in order to determine the real clinical importance of this treatment in the outcome of severe staphylococcal disease. It is necessary to identify groups of infants with severe sepsis in whom treatment with intravenous immunoglobulin might be useful.

\section{References}

${ }^{1}$ Bussel JB, Goldman A, Imbach P, Schulman J, Hilgartner MW. Treatment of acute idiopathic thrombocytopenia of childhood with intravenous infusions of gammaglobulin. $J$ Pediatr 1985;106:886-90.

2 Calvetti TA, Rubinstein A. Intravenous gamma-globulin in infant acquired immunodeficiency syndrome. Pediatr Infect Dis 1986;5(suppl):207-10.

${ }^{3}$ Imbach P, Barandun S, d'Apuzzo V. High dose intravenous gamma-globulin for idiopathic thrombocytopenic purpura in childhood. Lancet 1981;i:1228-31.

${ }^{4}$ Fischer GW, Hemming VG, Hunter $\mathrm{KW}$, et al. Intravenous immunoglobulin in the treatment of neonatal sepsis: therapeutic strategies in laboratory studies. Pediatr Infect Dis 1986;5(suppl):171-5.

5 von Muralt G, Sidiropoulos D. Experience with intravenous immunoglobulin treatment in neonates and pregnant women. Vox Sang 1986;51(suppl):22-9.

6 Johnston RB, Klemperer MR, Alper CA, Rosen FS. The enhancement of bacterial phagocytosis by serum: the role of complement components and two cofactors. J Exp Med 1969;124:1275-90.

${ }^{7}$ Marodi L, Leijh PCJ, Braat A, Daha M, van Furth R. Opsonic activity of cord blood sera against various species of microorganisms. Pediatr Res 1985;19:433-6.

${ }^{8}$ Muller-Eberhard HJ, Schreiber RD. Molecular biology and chemistry of alternative pathway of complement. Adv Immunol 1980;29:1-35.

9 van Furth R, Leijh PCJ, Klein F. Correlation between opsonic activity for various micro-organisms and composition of gammaglobulin preparations for intravenous use. J Infect Dis 1984;149:511-7.

10 Giver LB, Edwards MS, Anderson DC, Baker CJ. Immune globulin for intravenous use: enhancement of in vitro opsonophagocytic activity of neonatal sera. J Infect Dis 1985;151:217-20.

11 van Furth R, van Zwet ThL, Leijh PCJ. In vitro determination of phagocytosis and intracellular killing by polymorphonuclear and mononuclear phagocytes. In: Weir DM, ed. Handbook of experimental immunology. 3rd ed. Oxford: Blackwell Scientific, 1978:32.1-32.19.

12 Marodi L, Leijh PCJ, van Furth R. A micromethod for the separate evaluation of phagocytosis and intracellular killing of Staphylococcus aureus by human granulocytes and monocytes. J Immunol Methods 1983;57:353-61.

13 Kabat EA, Mayer MM. Experimental immunochemistry. 2nd ed. Springfield: Thomas, 1961:1275-90.

14 Armitage P. Statistical methods in medical research. Oxford: Blackwell, 1971.

15 Cohen ML. Staphylococcus aureus: biology, mechanisms of virulence, epidemiology. J Pediatr 1986;108:796-9.

16 Monteil M, Hobbs J. Selective immunodeficiency affecting staphylococcal response. Lancet 1987;ii:880-3.

17 Verburgh HA, van Dijk WC, Erne ME, Peters R, Peterson PK, Verhoef $J$. Quantitation of the third component of human complement attached to the surface of opsonized bacteria: opsonin-deficient sera and phagocytosis resistent strains. Infect Immun 1979;26:808-12.

Correspondence to Dr L Marodi, Department of Paediatrics, University Medical School of Debrecen, H-4012 Debrecen, POB:32, Hungary.

Accepted 18 September 1988 